\title{
Multidisciplinary characterisation of sedimentary processes in a recent maar lake (Lake Pavin, French Massif Central) and implication for natural hazards
}

\author{
E. Chapron ${ }^{1}$, P. Albéric ${ }^{1}$, D. Jézéquel ${ }^{2}$, W. Versteeg ${ }^{3}$, J.-L. Bourdier ${ }^{1}$, and J. Sitbon ${ }^{4}$ \\ ${ }^{1}$ Université d'Orléans, CNRS/INSU, Institut des Sciences de la Terre d'Orléans (ISTO)-UMR 6113, 1A rue de la Férollerie, \\ 45071 Orléans cedex 2, France \\ ${ }^{2}$ Institut de Physique du Globe de Paris-Université Paris Diderot-Paris 7, UMR 7154, 75205 Paris cedex 13, France \\ ${ }^{3}$ Renard Centre of Marine Geology, Krijgslaan S8, Ghent University, Ghent, Belgium \\ ${ }^{4}$ Radiologie \& Echographie Spécialisées, 45100 Orléans, France
}

Received: 9 April 2010 - Revised: 2 July 2010 - Accepted: 5 July 2010 - Published: 6 September 2010

\begin{abstract}
Sedimentation processes occurring in the most recent maar lake of the French Massif Central (Lake Pavin) are documented for the first time based on high resolution seismic reflection and multibeam bathymetric surveys and by piston coring and radiocarbon dating on a sediment depocentre developed on a narrow sub aquatic plateau. This new data set confirms the mid Holocene age of maar lake Pavin formation at $6970 \pm 60 \mathrm{yrs}$ cal BP and highlights a wide range of gravity reworking phenomena affecting the basin. In particular, a slump deposit dated between AD 580-640 remoulded both mid-Holocene lacustrine sediments, terrestrial plant debris and some volcanic material from the northern crater inner walls. Between AD 1200 and AD 1300, a large slide scar mapped at $50 \mathrm{~m}$ depth also affected the southern edge of the sub aquatic plateau, suggesting that these gas-rich biogenic sediments (laminated diatomite) are poorly stable. Although several triggering mechanisms can be proposed for these prehistoric sub-aquatic mass wasting deposits in Lake Pavin, we argue that such large remobilisation of gas-rich sediments may affect the gas stability in deep waters of meromictic maar lakes. This study highlights the need to further document mass wasting processes in maar lakes and their impacts on the generation of waves, favouring the development of dangerous (and potentially deadly) limnic eruptions.
\end{abstract}

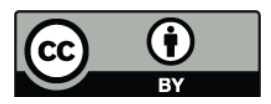

Correspondence to: E. Chapron (emmanuel.chapron@univ-orleans.fr)

\section{Introduction}

Maar lake basin fills are considered as key environments for paleoclimate reconstructions (Thouveny et al., 1994; Siffedine et al., 1996; Oldfield, 1996; Brauer et al., 2008), but if some limnological studies describe the genesis of sediments (Schettler and Albéric, 2008), little is known in these volcanic environments about the triggering factors of gravity reworking phenomena and related natural hazards (e.g. rock falls, sub aqueous slides, impact waves, crater outburst, lahars, cf. Giresse et al., 1991; Chondrogianni et al., 1996; Bacon et al., 2002; Anselmetti et al., 2008; Anzidei et al., 2008; Bani et al., 2009; Joyce et al., 2009). Investigating sub-aquatic mass movements in such basins is, however, required when carrying out risk assessment related to natural hazards. There is also a need to improve our understanding of the factors maintaining slope stability and those triggering sub-aquatic mass movements. Slope instability in marine and lacustrine environments is generally caused by erosion, sedimentation, gas hydrate dissociation, earthquake shaking, lake (sea-) level change and/or wave action (Nisbet and Piper, 1998; Locat and Lee, 2002; Van Rensbergen et al., 2002; Chapron et al., 2006; Masson et al., 2006) and can generate sub-aquatic landslides, which occasionally result in the development of violent surface waves (tsunamis, seiche effects). Maar lake basins being frequently characterized by steep slopes, sub aquatic plateaus, a conical morphology and no large inflows (Chondrogianni et al., 1996; Ramrath et al., 1999; Anzidei et al., 2008; Mazzanti and Bozzano, 2009), they constitute peculiar environments to investigate the impact of sub-aquatic landslide(s) along the shorelines and the possible generation of violent waves or crater outburst(s).

Published by Copernicus Publications on behalf of the European Geosciences Union. 


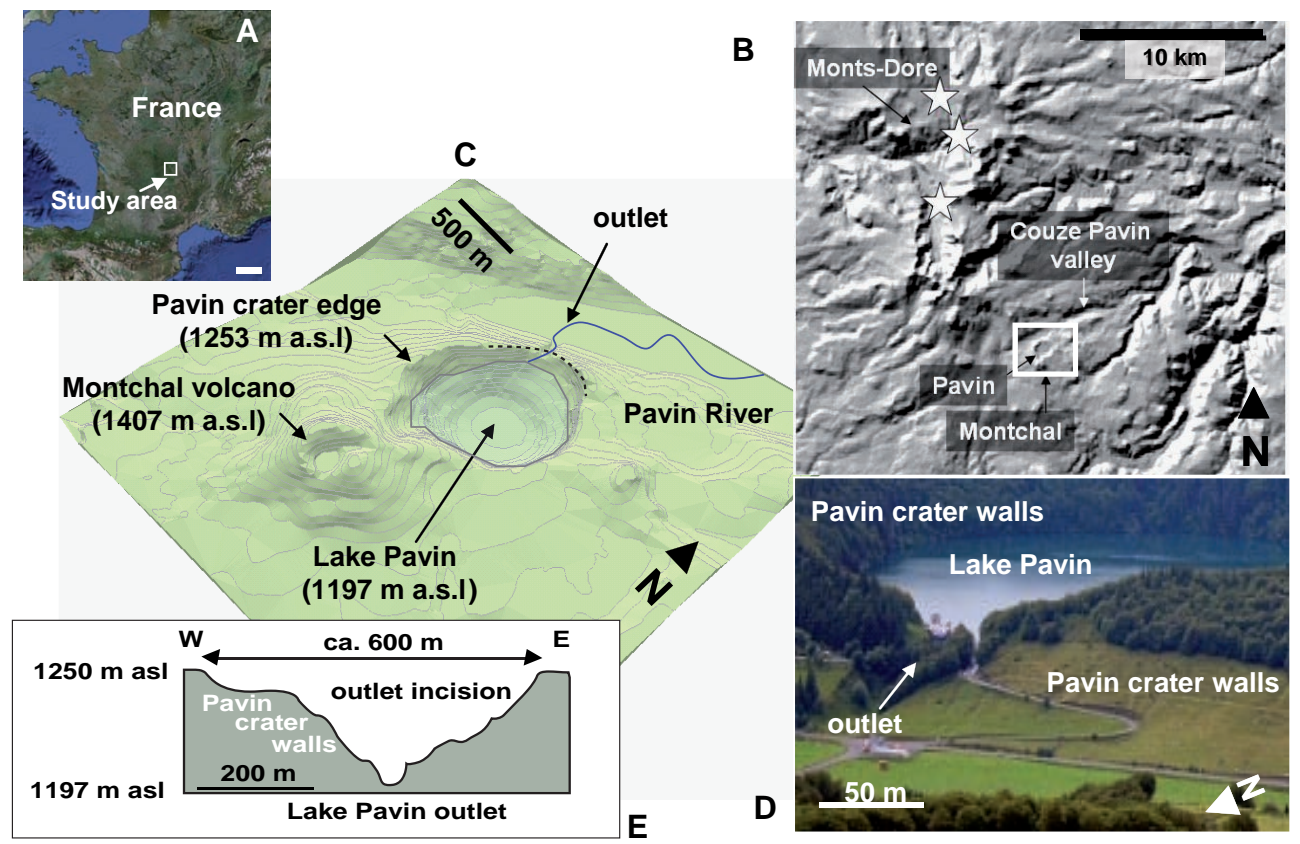

Fig. 1. General location (white bar corresponding to $100 \mathrm{~km}$ ) of the study area (A). Geomorphology map of Pavin crater and the Couze Pavin valley in the Mont-Dore mountain range, French Massif Central (B). White stars indicate historical earthquake epicentres in the MontDore area, and the white square localize the 3-D view of the Digital Elevation Model (DEM) of the Montchal volcano-lake Pavin complex presented in (C). Picture illustrating the lake outlet incised along the northern flank of Lake Pavin crater (D). On the DEM presented in (C), the black dashed line localise the topographic profile of the lake outlet incision given in $(\mathbf{E})$.

In meromictic maar lakes where the development of a permanent anoxic deep water body (i.e. monimolimnion) can favour high concentrations of biogenic and mantle-derived gases (such as $\mathrm{CO}_{2}$ and $\mathrm{CH}_{4}$, Camus et al., 1993; AeschbachHertig et al., 1999), an additional natural hazard may also be related to deep water degassing (either spontaneously or induced by an external factor, Sigurdsson et al., 1987; Rice, 2000; Caracausi et al., 2009). Natural Hazards assessments in several large crater lakes in North America and Italy were thus significantly improved over the last decades when integrating high resolution acoustic mapping techniques, sediment cores investigations, geochemical models of lakes waters and numerical modelling of landslide impact in lakes (cf. Morgan et al., 2003; Anzidei et al., 2008; Mazzanti and Bozzano, 2009). These approaches were, however, never applied in recently formed smaller maar lake system, although they might be necessary to fully understand driving processes resulting in gas burst disasters such as the ones of Lake Nyos in 1986 (cf. Motts and Woods, 2010).

Lake Pavin $\left(45^{\circ} 30^{\prime} \mathrm{N}, 2^{\circ} 53^{\prime} \mathrm{E}\right)$ is the only meromictic maar lake in France. According to Bourdier (1980), this maar lake and its surrounding crater wall (Fig. 1) where formed during the most recent period of volcanic activity in the French Massif Central: a large phreatomagmatic eruption dated around $6000{ }^{14} \mathrm{C}$ yr BP (Juvigné and Gilot, 1986; Guenet and Reille, 1991; Juvigné, 1992). Observations of ongoing gravity phenomena along the inner crater walls, re- cent debris flow deposits in the Couze Pavin valley downstream from Lake Pavin and also some possible minor volcanic events at the vicinity of Lake Pavin, where however suggested by Lavina and del Rosso (2008).

In this study we present for the first time the main sedimentary environments of Lake Pavin identified by high resolution seismic reflection and multibeam bathymetric surveys. Its basin fill lithology and chronology is then presented in detail by piston coring and radiocarbon dating. We finally document the dominating sedimentary processes, discuss the potential origin of volcanic materials and mass wasting deposits identified within the basin fill and evaluate the potential Natural hazards associated with mass wasting processes in recent meromictic maar lakes.

\section{Setting}

Lake Pavin is a $92 \mathrm{~m}$ deep (Fig. 2) almost circular (750 m diameter) maar located at an altitude of $1197 \mathrm{~m}$ in the French Massif Central. Its drainage basin is densely covered by mixed deciduous/coniferous forest. The catchment area is delimited by the crater rim (reaching an altitude of $1253 \mathrm{~m}$ ) but culminates at an altitude of $1407 \mathrm{~m}$ along the northern flank of the Montchal cinder cone (Fig. 1). The lake outlet occurs at the NNW of the lake where a wide channel cuts the crater walls and drains into the Pavin River towards the 
SE in the Couze Pavin valley (Fig. 1). The pioneer study of Delibrias et al. (1972) combining short coring near the lake shore and radiocarbon dating documented significant age inversions within mid Holocene lacustrine sediments, suggesting the occurrence of sub-aqueous gravity reworking phenomena.

Lake Pavin monimolimnion occurring today from ca. 60 $92 \mathrm{~m}$ water depth is reflected both by water conductivity measurements (cf. Fig. 3) and by enhanced $\mathrm{CO}_{2}, \mathrm{CH}_{4}$ and dissolved organic carbon content (Albéric et al., 2000; Assayag et al., 2008). These anoxic deep waters favoured the preservation of annually laminated organic-rich sediments over the last 700 years (Stebich et al., 2005; Schettler et al., 2007): a seasonal succession of a thick light summer diatom layer and a thin dark autumn layer with terrestrial plant remains from the vicinity of the lake as major constituent.

\section{Methods}

\subsection{Acoustic mapping}

The basin fill geometry of Lake Pavin has been documented by a high-resolution seismic reflection survey conducted by the Renard Center of Marine Geology in fall 2002. During this survey, ca. $15 \mathrm{~km}$ of profiles (Fig. 2) were aquired using a Geoacoustics $3.5 \mathrm{kHz}$ pinger device and a regular global positioning system (GPS).

In spring 2008, a detailed lake floor bathymetric map (Fig. 2) has been established using a Reason Seabat 8101 multibeam echosounder mounted on the Survex I mapping vessel including differential GPS positioning and an inertialnavigation system. This multibeam bathymetric survey combined with the $3.5 \mathrm{kHz}$ profile shown in Fig. 3 allowed optimizing the location of a long coring site (PAV08).

\subsection{Sediment cores}

At site PAV08 $\left(45^{\circ} 29.86^{\prime} \mathrm{N} / 2^{\circ} 53.24^{\prime} \mathrm{E}\right)$ sediments were retrieved in $46.2 \mathrm{~m}$ water depth, from an UWITEC coring platform using a set of piston corer and a gravity corer at two nearby locations as shown in Fig. 4. This strategy allowed the complete recovery of a $509 \mathrm{~cm}$ long sedimentary section. Sediment core lithologies (Fig. 5) were documented by (i) digital radiographies on a Siemens Axiom Iconos R200 coupled with a Fugi Profect digital printer and (ii) logging on a GEOTEK multi-sensor track (magnetic susceptibility (MS), gamma density and P-wave velocity). The sediment physical properties were measured with a $1 \mathrm{~cm}$ interval and complete core lithologies were video captured. Together with visual observations, this data set allows establishing a detailed lithology log (Figs. 4 and 6). Volcanic sandy debris at $180 \mathrm{~cm}$ core depth and below $476 \mathrm{~cm}$ (Fig. 7) were also sampled, sieved, classified and counted using the binocular and thin sections. Nine samples were selected for AMS radiocarbon dating at Poznan Radiocarbon Laboratory, Poland (Table 1,

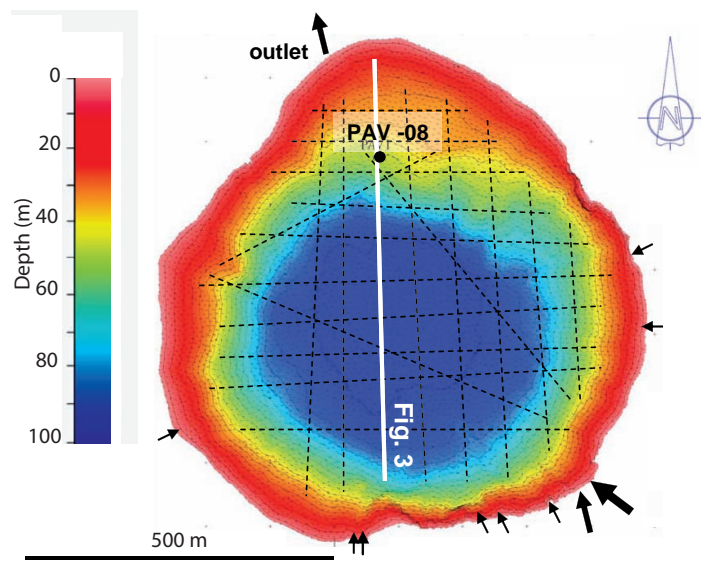

Fig. 2. Lake Pavin multibeam bathymetry map (isobaths in meters) with the $3.5 \mathrm{kHz}$ seismic grid (dashed lines), PAV08 coring site and the location of the pinger profile shown in Fig. 3. Black arrows indicate the location of several small inlets along the southern lake shore draining Montchal volcano slopes and the location of the lake outlet.

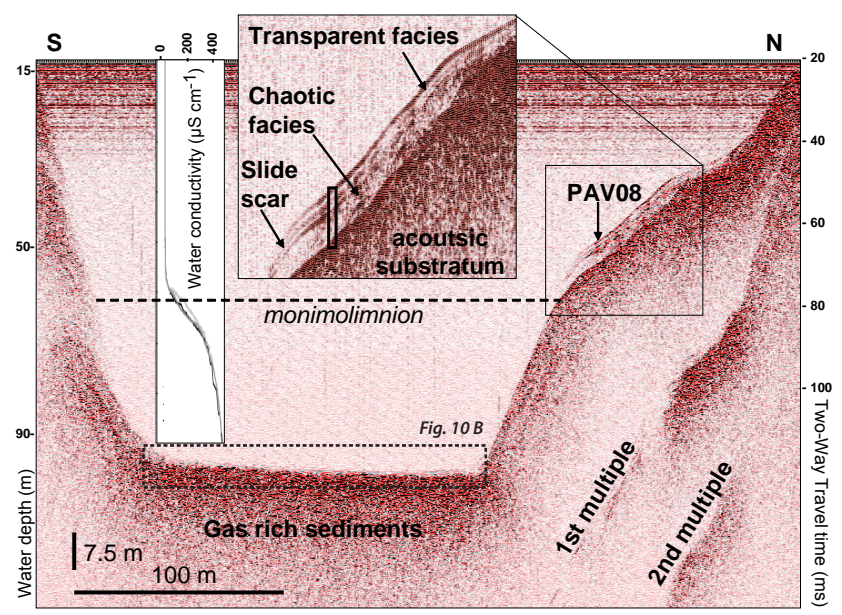

Fig. 3. High resolution seismic reflection profile $(3.5 \mathrm{kHz})$ across the basin showing the main acoustic facies identified in Lake Pavin and the seismic stratigraphy at PAV08 coring site. Water conductivity measurements illustrating the location of the lake monimolimnion at $60 \mathrm{~m}$ water depth (after Assayag et al., 2008) are also illustrated. The enlarged portion of this profile in the deep basin presented in Fig. 10b is as well indicated.

Fig. 4). Calibrations of radiocarbon ages were performed by using the CalPal-2007-Hulu calibration curve (Weninger and Jöris, 2004).

\section{Results}

\subsection{Acoustic data}

A maximum acoustic penetration of $6 \mathrm{~ms}$ two-way travel time (TWT) (corresponding to ca. $450 \mathrm{~cm}$ when applying a mean P-wave velocity of $1500 \mathrm{~ms}^{-1}$ ) was achieved with the $3.5 \mathrm{kHz}$ device on a little plateau characterizing the northern 


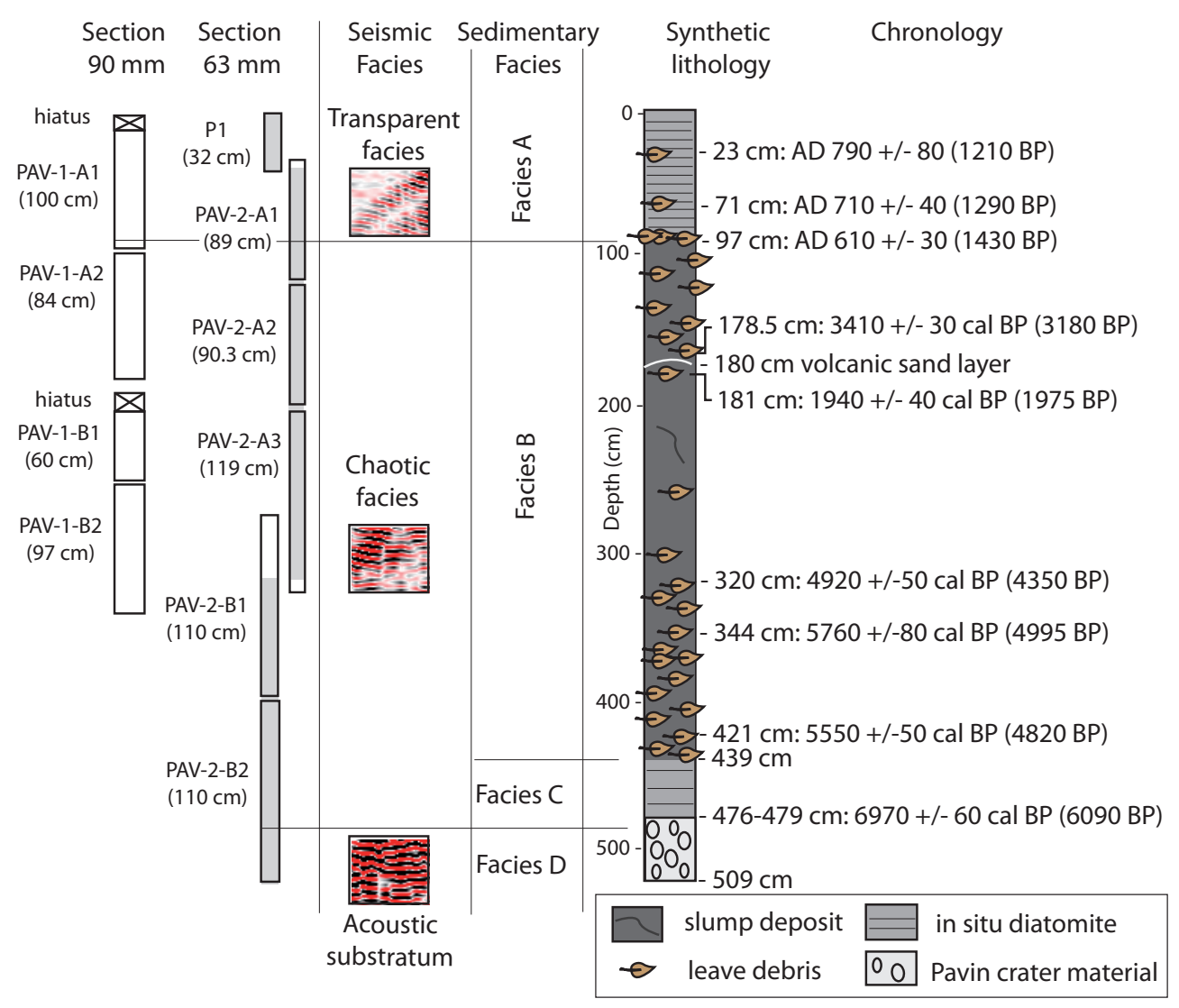

Fig. 4. PAV08 synthetic core lithologies illustrating the chronology of sedimentary facies (A, B, C and D) and corresponding seismic facies discussed in the text. An abrupt increase of gamma density at $97 \mathrm{~cm}$ core depth matches the transition from sedimentary facies A to B and the limit between the upper transparent seismic facies and the basal seismic facies. Similarly, a major increase in sediment gamma density within sedimentary facies D corresponds to the top of the acoustic substratum. The occurrences of numerous leaves debris and of a coarse sand layer in facies B interpreted as a slump deposit suggest that a significant part of the material was reworked from the inner crater walls and remoulded with lacustrine sediments.

Table 1. Radiocarbon and calibrated ages retrieved from core PAV08 on terrestrial organic macro remains (leaves) and bulk sediment (between 476 and $479 \mathrm{~cm}$ ).

\begin{tabular}{cclcl}
\hline $\begin{array}{l}\text { Depth } \\
(\mathrm{cm})\end{array}$ & Laboratory & $\begin{array}{l}\text { Radioicarbon } \\
\text { age }\end{array}$ & $\begin{array}{c}\text { Calibrated age } \\
(1 \text { sigma })\end{array}$ & Material \\
\hline 23 & Poz-31851 & $1210 \pm 65 \mathrm{BP}$ & AD 790 \pm 80 & leaves \\
71 & Poz-27046 & $1290 \pm 35 \mathrm{BP}$ & AD 710 \pm 40 & leaves \\
97 & Poz-27047 & $1430 \pm 21 \mathrm{BP}$ & AD 610 \pm 30 & leaves \\
178.5 & Poz-31849 & $3180 \pm 35 \mathrm{BP}$ & $3410 \pm 30 \mathrm{cal} \mathrm{BP}$ & leaves \\
181 & Poz-31850 & $1975 \pm 35 \mathrm{BP}$ & $1940 \pm 40 \mathrm{cal} \mathrm{BP}$ & leaves \\
320 & Poz-27048 & $4350 \pm 35 \mathrm{BP}$ & $4920 \pm 50 \mathrm{cal} \mathrm{BP}$ & leaves \\
344 & Poz-27050 & $4995 \pm 35 \mathrm{BP}$ & $5760 \pm 80 \mathrm{cal} \mathrm{BP}$ & leaves \\
421 & Poz-27051 & $4820 \pm 40 \mathrm{BP}$ & $5550 \pm 50 \mathrm{cal} \mathrm{BP}$ & leaves \\
$476-479$ & Poz-27052 & $6090 \pm 40 \mathrm{BP}$ & $6970 \pm 60 \mathrm{cal} \mathrm{BP}$ & bulk \\
& & & & sediment \\
\hline
\end{tabular}

part of the lake basin between 30 and $50 \mathrm{~m}$ water depths (Fig. 3). Two main acoustic facies can be identified within this sediment depocentre above the acoustic substratum: a transparent to chaotic basal unit $5 \mathrm{~ms}$ TWT thick (ca. $375 \mathrm{~cm}$ ) and a thin $(1 \mathrm{~ms}$ TWT, ca. $75 \mathrm{~cm})$ transparent upper unit developing a draping geometry. This upper unit is also onlaping towards the northern lake shore at ca. $30 \mathrm{~m}$ water depths. Towards the deep basin, the depocentre is on the contrary ending abruptly and developing diffractions below $50 \mathrm{~m}$ water depths. The steep basin slopes of this maar lake are elsewhere essentially corresponding to the acoustic substratum that locally forms diffractions, while the acoustic signal is very quickly absorbed in the deep flat basin.

On the 3-D view of Lake Pavin bathymetric map shown in Fig. 8, the steep basin slopes are characterized by the development of numerous canyons occurring downstream from the small inlets draining Montchal volcano (Fig. 2). Along the northern slopes a ca. $350 \mathrm{~m}$ wide and $4 \mathrm{~m}$ high fresh slide scar is clearly identified at $50 \mathrm{~m}$ water depth along the southern edge of the plateau. Along the western part of the basin, the lake floor is also locally characterized (i) by a hummocky topography below $80 \mathrm{~m}$ water depths and (ii) by a wavy topography between 40 and $50 \mathrm{~m}$ water depths. 
These typical seismic facies and lake floor morphologies highlight that very little sediments are present along the steep slopes of Lake Pavin and that gas rich sediments essentially accumulate in the deep basin. The slopes are, in addition, locally affected by a wide spectrum of gravity reworking phenomena. In particular, the basal unit of the small sediment depocentre on the plateau has the typical geometry of a mass wasting deposit (MWD, cf. Schnellmann et al., 2002; Chapron et al., 2006; Fanetti et al., 2008) and the steep southern side of the depocentre appears to be affected by a fresh slide scar clearly visible on the bathymetric data. Hummocky morphologies at the western edge of the deep basin also suggest the occurrence of former MWDs draped by recent sediments. In addition, wavy morphologies identified upslope from these former MWDs indicate the development of soft sediment creeping phenomena (cf. Mulder and Cochonat, 1996; Chapron et al., 2004; Ledoux et al., 2010).

\subsection{Sediment cores}

Four main sedimentary facies are identified at the PAV08 coring site (Figs. 4 and 5).

Facies A is occurring from the lake floor to $97 \mathrm{~cm}$ core depth, and consists in greenish finely laminated sandy silts rich in diatoms blooms. This facies has very low MS values, a low gamma density (between 1 and $1.1 \mathrm{gcm}^{-3}$ ) and numerous gas expansion cracks visible on radiographies.

Facies B (occurring between $97 \mathrm{~cm}$ and $439 \mathrm{~cm}$ core depth) consists in dark grey to blackish sandy silts, rich in organic debris (leaves) as show in Fig. 4, but the top of facies B consist in a striking layer (one centimetre thick) made only of leaves debris and leaves. Sediments in facies B are bearing low MS values but contrasting and fluctuating gamma densities (between 0.95 and $1.8 \mathrm{gcm}^{-3}$, cf. Fig. 6). On radiographies these sediments are rather homogenous except at $180 \mathrm{~cm}$ core depth, where a one centimetre thick coarse sand layer produces a clear density contrast. This sandy layer is only clearly visible in section PAV-1-A2. It has been sampled, sieved (cf. Fig. 7) and its composition is described in the following section.

Facies C observed between $439 \mathrm{~cm}$ and $476 \mathrm{~cm}$ core depth corresponds to brownish laminated sandy silt sediments bearing few diatom bloom layers. These sediments have a mean density of $1.1 \mathrm{gcm}^{-3}$ and are affected by frequent gas expansion cracks identified both visually and on radiographies.

Facies D occurs from $476 \mathrm{~cm}$ to the base of the core (at $509 \mathrm{~cm}$ ) and contrasts sharply with overlying sediments: it consists in light grey to brownish gravels and pebbles in a coarse sand and silty matrix as shown in Fig. 7. This basal facies yields a maximal gamma density (fluctuating between 2.31 and $3.7 \mathrm{gcm}^{-3}$ ) as clearly shown on radiographies.
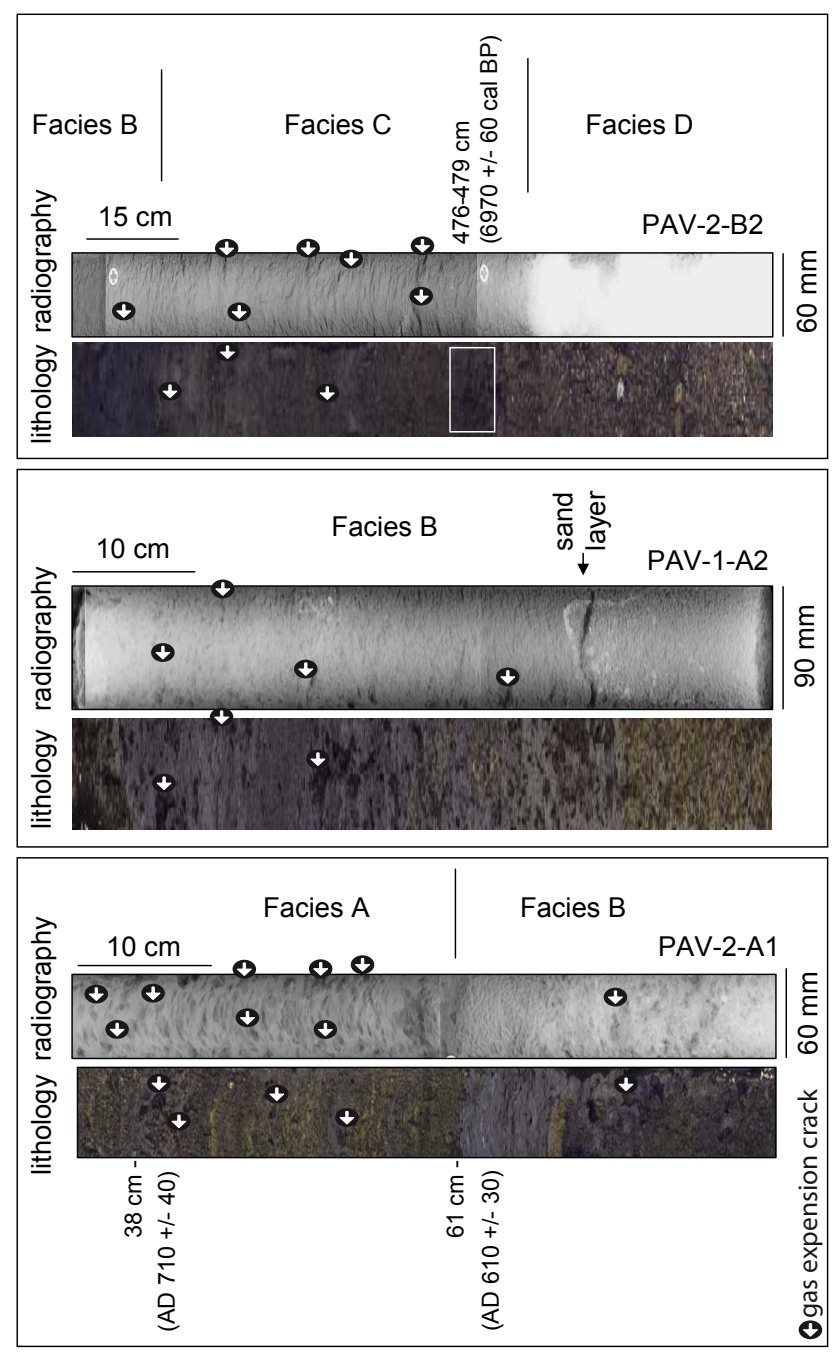

Fig. 5. Illustrations of sedimentary facies A, B, C and D in PAV08 cores. Both lithologies and digital radiographies are characterized by frequent gas expansion cracks (localised by white arrows in dark circles) in sedimentary facies A and C. Facies B is showing less frequent expansion cracks and consisting of a mixture of lacustrine, terrestrial and volcanic materials having different colours and densities. Facies D is clearly contrasting with overlying sediments in terms of density, mineralogy and grain size.

\subsection{Volcanic material}

Facies D consists, in decreasing order of abundances, of crystalline (plutonic and metamorphic) rocks (ca. $40 \%$ in clast number), various trachyandesitic lavas (ca. 30\%), basaltlooking lavas, and a few percents of variously vesicular, yellowish pumices.

The sandy layer intercalated within facies B contains the same lithological types as facies $\mathrm{D}$, although in different proportions, being richer in trachyandesitic lavas (ca. 50\%) and pumices (ca. 10\%), and notably poorer in crystalline basement fragments (ca. 10\%). 


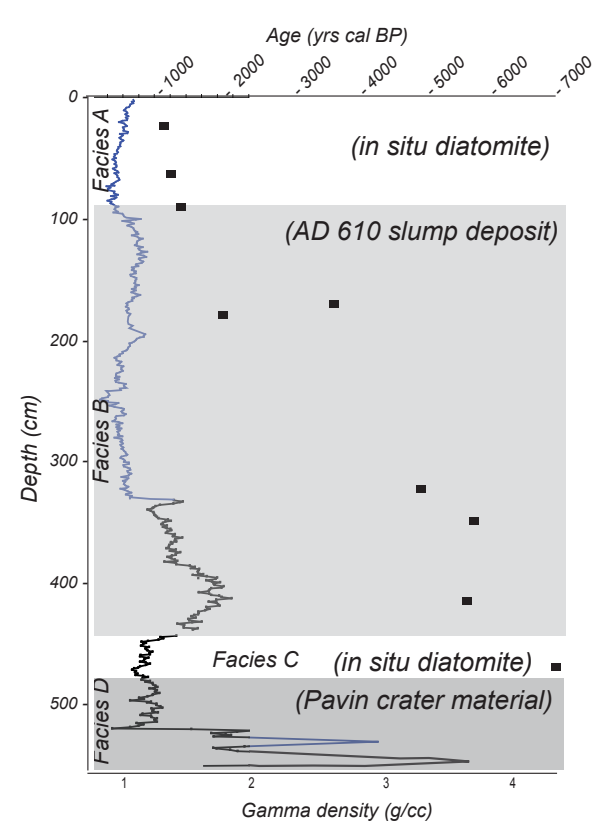

(A) Lake Pavin plateau (PAV08)

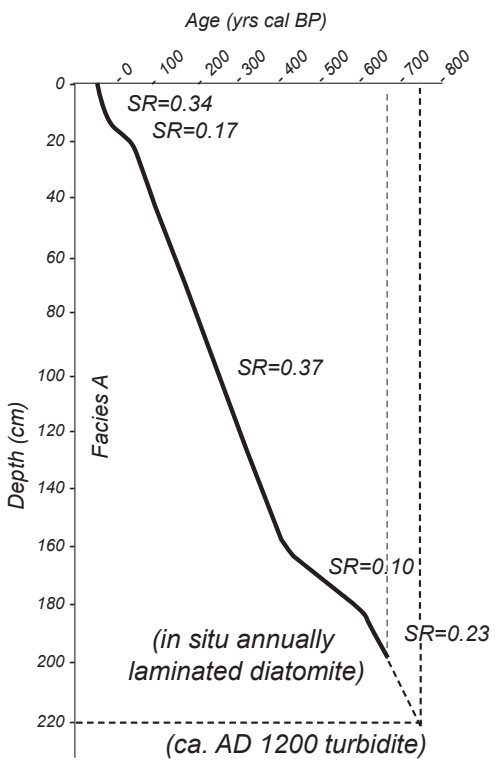

(B) Lake Pavin basin (PAV1-3)

Fig. 6. Ages of mass wasting events in Lake Pavin. (A) Age-depth model and synthetic gamma density profile of core PAV08 (this study). Dark square indicate AMS radiocarbon dates in yrs cal BP. (B) Age-depth model and simplified lithology retrieved in gravity core PAV1-3 and freeze core P1 in the centre of Lake Pavin deep basin published and dated by Stebich et al. (2005), Schettler et al. (2007) and Schwalb et al. (2009) based on varve counting. Mean sedimentation rates (SR) deduced from varve counts in in situ diatomite are indicated. The lower mean SR from core PAV1-3 is extrapolated down core to estimate the age of the top of a large turbidite documented by Schwalb et al. (2009) at $220 \mathrm{~cm}$ below the lake floor.

The variously vesicular, yellowish pumice clasts are similar in texture and mineralogy to the pumices from the Pavin eruption as known in the pyroclastic products exposed all around the Pavin crater (Bourdier, 1980). Trachyandesite lavas are common in the neighbouring PlioQuaternary Monts-Dore volcanic complex (Fig. 1). Lava clasts of basaltic affinity in terms of coloration and texture under the binocular, can be derived either from the Holocene Montchal lava flow that is cut through by the Pavin crater, or from older ubiquitous basaltic volcanism in the area. Trachyandesite lavas and crystalline basement rocks are not exposed above the Lake Pavin but might be exposed below the lake level. The various lithologies found in our samples (facies D and sandy layer form facies B) can thus be well explained as material reworked along the slopes of the Pavin crater.

\subsection{Core chronology}

The nine radiocarbon samples dated by AMS (Table 1, Fig. 4) have a Holocene age and are in chronological order, except two age inversions at 178.5 and $344 \mathrm{~cm}$ core depth (Fig. 6). These age inversions clearly indicate that facies B sediments are reworked. This interpretation is further supported by the striking amount of leaves irregularly distributed within this facies and by the significant variability of sediment gamma density within Facies B.

\section{Discussion}

\subsection{Lake basin evolution}

Facies A covers the last 1400 years at site PAV08 and following Schettler et al. (2007), this facies is interpreted as in situ annually laminated diatomite. Three radiocarbon ages in chronological order in this $97 \mathrm{~cm}$ thick facies at site PAV08 (Figs. 4 and 6) allows establishing two contrasting mean sedimentation rates: ca. $4 \mathrm{~mm} /$ year from $\mathrm{AD} 610 \pm 30$ to $\mathrm{AD} 790 \pm 80$, but only $0.2 \mathrm{~mm} / \mathrm{yr}$ from $\mathrm{AD} 790 \pm 80$ to present. For comparison, in the deepest part of the lake basin where focusing of settling particle fluxes may occur (Schettler and Albéric, 2008), the chronology established by Schettler et al. (2007) based on varve counting (cf. Fig. 6) is reflecting mean sedimentation rates ranging between 1.0 and $3.7 \mathrm{~mm} /$ year since AD 1300. Similar variable accumulation rates were also deduced from $\mathrm{Si}$ and $\mathrm{Pb}$ radiometric methods (Martin et al., 1992). Mean sedimentation rates seem therefore to be significantly variable within the lake basin and also through time. The occurrence of diatoms blooms resulting frequently in the deposition at the lake floor (both on the plateau at site PAV08 and in the deep basin) of centimetric layers made essentially of diatoms remains can explain the high values of mean sedimentation rates observed in this lake. In agreement with the study of Stebich et al. (2005), this 


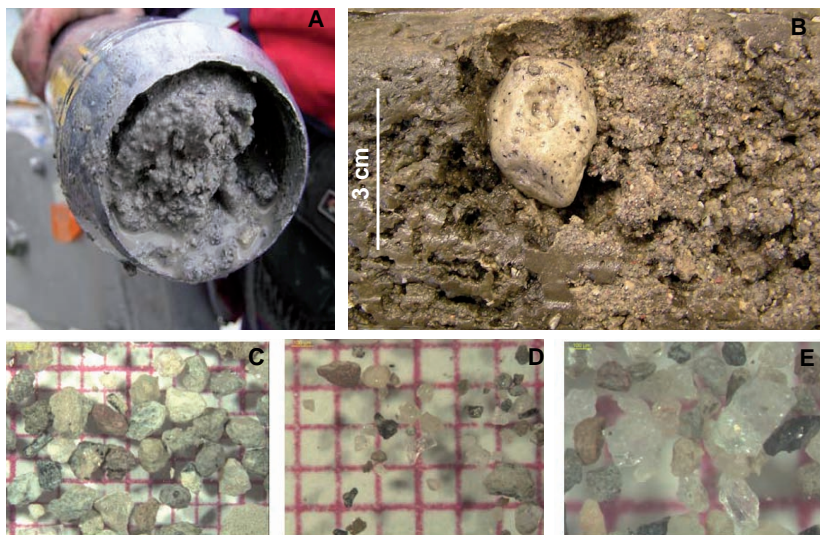

Fig. 7. Pictures of volcanic materials retrieved in PAV08 core discussed in the text. Facies D in the core catcher $(\mathbf{A})$ and at the base of the core (B) is characterized by frequent angular gravels and pumices stones. The coarse sand fraction $(\mathbf{C})$ and the medium sand fraction (D and $\mathbf{E}$ ) of the volcanic sandy layer from facies B have a similar composition than facies D. Scale in pictures C, D, and E is provided by a $1 \mathrm{~mm}$ red grid.

suggests that both climate and human impact (in particular forest clearing, cultivation and grazing) in the catchment area are significantly controlling sediment accumulation rates in Lake Pavin.

Following the classification of Mulder and Cochonat (1996), Facies B is interpreted as a slump deposit reworking some volcanic material, but essentially mid Holocene lacustrine sediments and terrestrial organic materials (leaves). This slump deposit is dated to AD $610 \pm 30 \mathrm{yrs}$ (i.e. between AD 580-640). Its extension over the plateau documented on seismic profiles suggest that its main sediment source area was probably located toward the North near the present lake shore and eventually extending down to $30 \mathrm{~m}$ (present-day) water depth, an area where the acoustic substratum widely outcrops (cf. Fig. 3).

The onset of Facies C organic-rich lacustrine sedimentation is dated to $6970 \pm 60 \mathrm{yrs}$ cal BP and is interpreted as in situ biogenic material (a laminated diatomite) settling from the water column in the recently formed maar Lake Pavin. The absence of any organic debris in this facies at site PAV08 suggests that the vegetation cover of the crater walls kept limited during this early phase of the system. Pollen investigations should, however, be realized in this facies to precise the evolution of the vegetation cover.

Facies D is interpreted as the upper part of the Pavin crater material and correlated to the acoustic substratum. This correlation suggests that the sub-aquatic plateau well identified on acoustic data is corresponding to a collapsed wall of the crater at the end of the eruption. The formation of this crater can in addition be dated to ca. $6090{ }^{14} \mathrm{C} \mathrm{BP}(6970 \pm 60 \mathrm{yrs}$ cal $\mathrm{BP}$ ), in agreement with former regional studies (Juvigné and Gilot, 1986; Guenet and Reille, 1991; Juvigné, 1992).

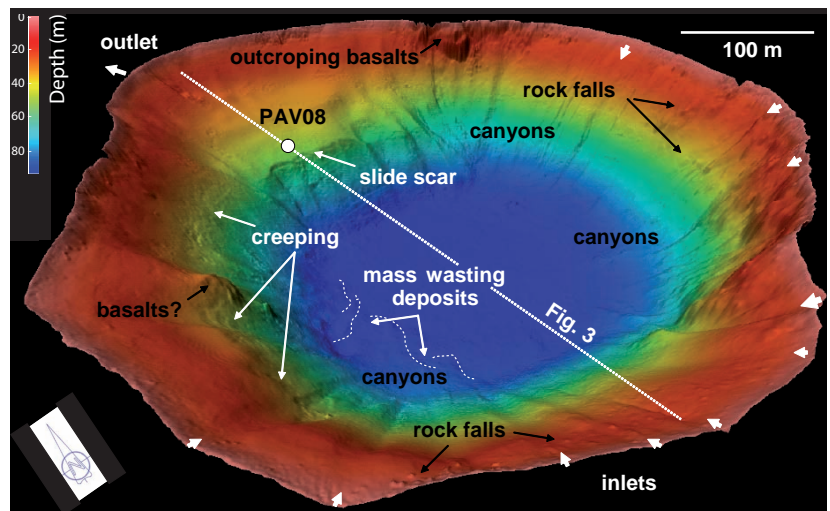

Fig. 8. 3-D bathymetric view of Lake Pavin illustrating the impact of a wide range of gravity reworking phenomena in the basin. In addition to a fresh slide scar and evidences for creeping and mass wasting deposits, some boulders resulting from rock falls are as well locally identified. Numerous canyons are also characterizing the steep slopes of the basin.
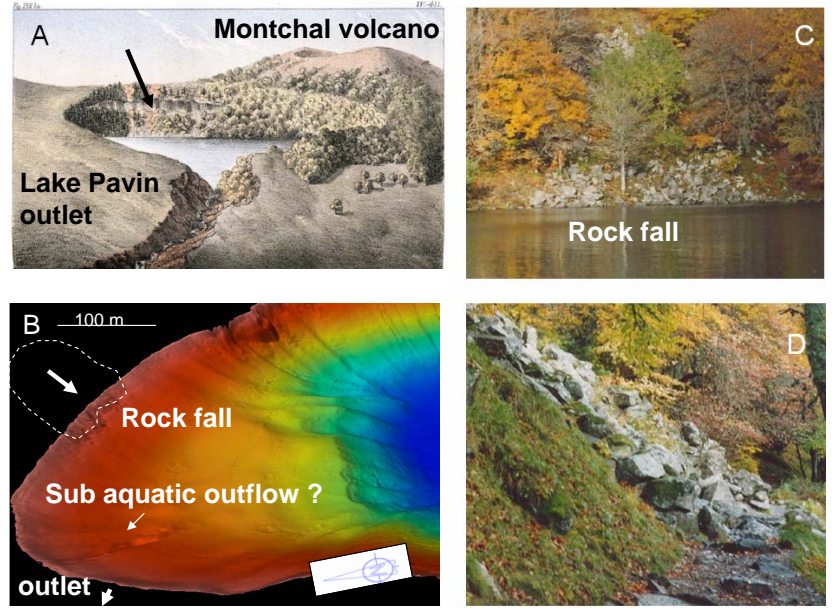

Fig. 9. Instability of Pavin crater rim materials and its influence on Lake Pavin. (A) Picture of the painting form Lecoq (1867) illustrating outcropping Montchal lavas (black arrow) and the morphology of the lake outlet before significant human impact. (B) Oblique view of multibeam bathymetric map of Lake Pavin illustrating the limited extension of on-going rock falling into the lake and the possible signature of a subaquatic outflow near the lake outlet. (C) and (D) are pictures of the largest rock fall event identified around the lake.

\subsection{Dominating sedimentary processes in Lake Pavin}

Very soon after the Pavin crater formation ca. 7000 yrs ago, groundwater supply and meteoric rain fall flooded the crater. The occurrence of a little plateau (Facies D) between 30 and $50 \mathrm{~m}$ water depths in the northern side of Lake Pavin allowed the development of a sediment depocentre resulting from (i) the settling of organic rich biogenic sediments (diatomite, Facies $\mathrm{C}$ and A) and (ii) the freezing in $\mathrm{AD} 610 \pm 30$ of a ca. $340 \mathrm{~cm}$ thick slump (Facies B). 

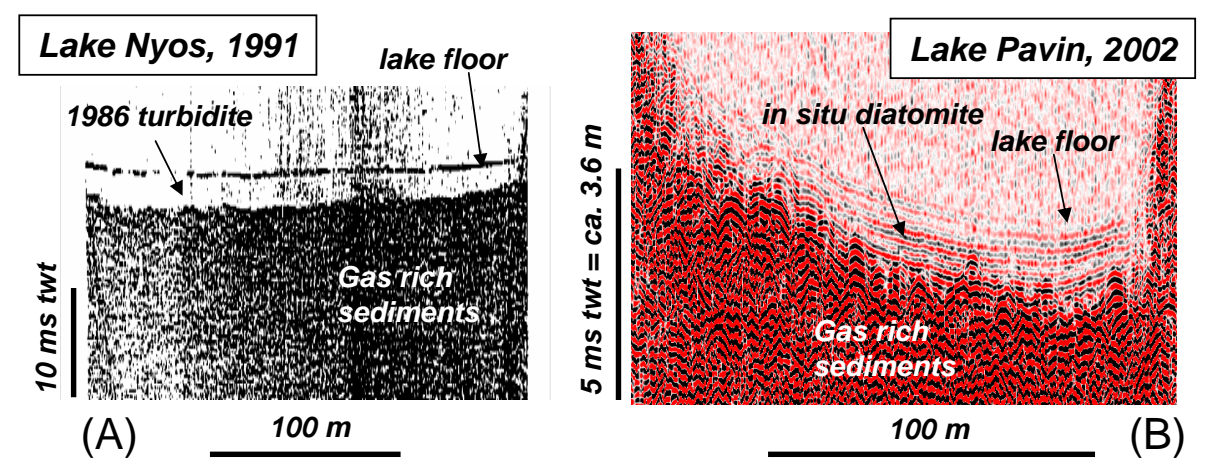

Fig. 10. Comparison of high-resolution $(3.5 \mathrm{kHz})$ seismic profiles in two recent meromictic maar lake deep flat basins floors: lakes Nyos (A) and Pavin (B). Lake Nyos (Cameroon, $220 \mathrm{~m}$ deep) analogue seismic profile taken by K. Kelts in February 1991 (modified after Leenhardt, 1991) highlights the formation of a large turbidite (up to $4 \mathrm{~m}$ thick) after the catastrophic and deadly limnic eruption from 1986 . Lake Pavin digital seismic profile (zoom section from the profile shown in Fig. 3), illustrate an up to $1 \mathrm{~m}$ thick stratified acoustic facies formed by authigenic sedimentation (in situ diatomite). At depths, both lake basins are characterized by no acoustic penetration due to significant gas content in the sediments.

More recently, a second slope failure at $50 \mathrm{~m}$ water depth along the southern edge of this plateau, formed a clear slide scar and reworked towards the deep basin all sediments from the crater walls between 50 and ca. $90 \mathrm{~m}$ water depths. Based on multibeam bathymetric data at the edge of the plateau and along the slide scar, the maximum volume of this second event can be estimated to ca. $150000 \mathrm{~m}^{3}$ (assuming that a $4 \mathrm{~m}$ thick and $350 \mathrm{~m}$ large sediment pile was reworked over a distance of ca. $100 \mathrm{~m}$ ) but its age is presently unknown. It however probably occurred shortly before AD 1300, because: (i) the first $198 \mathrm{~cm}$ in the deep basin consist in $700 \mathrm{yrs}$ of in situ annually laminated diatomites according to the agedepth model established by Schettler et al. (2007) (Fig. 6) and (ii) a plurimetric mass wasting deposit covered by a large turbidite deposit was documented in the deep basin by piston coring between 650 and $220 \mathrm{~cm}$ below the lake floor (Schwab et al., 2009). As shown in Fig. 6, a rough extrapolation of the mean sedimentation rate deduced from varve counts by Schettler et al. (2007) between 198 and $220 \mathrm{~cm}$ below the lake floor (i.e. to the remaining $22 \mathrm{~cm}$ of laminated diatomites documented above the turbidite deposit), suggest that the turbidite was deposited around $750 \mathrm{yrs}$ cal BP (i.e. around AD 1200). The slide scar identified on multibeam bathymetric data at the edge of the plateau may thus have formed around $750 \mathrm{yrs}$ cal BP. However, this age should be confirmed by radiocarbon dating.

Ongoing rock falls along the sub-aerial inner crater walls are locally originating from outcropping Montchal volcano basaltic lavas and are affecting the dense vegetation cover (Fig. 9). Only one larger rock fall deposit is locally reaching the lake shore and has a limited impact along littoral subaquatic environments according to the bathymetric data. Former rock falls are, in addition, documented in the lake basin between 1 and $40 \mathrm{~m}$ water depths by few boulders locally identified on the bathymetric data (Fig. 8).

\subsection{Possible triggering factors for mass wasting processes}

Limited rock falls affecting the Montchal volcano basaltic lavas along the sub-aerial inner crater walls of Lake Pavin can be related either to congelifraction processes or to ground shaking during an earthquake. Frost-shattering is however probably a dominating process because (i) the crater walls are snow covered every year, (ii) the lake surface is frozen almost every winter, and (iii) most of the inlets draining into the lake are springs occurring at the base of these outcropping basaltic lavas. Rock falls are thus interpreted as resulting both from the freezing and expansion of water, and from the steep slopes of the crater walls.

Soft-sediment gravity reworking phenomena in lakes can either be triggered by ground accelerations and sediment liquefaction during a single earthquake (Siegenthaler et al., 1982; Chapron et al., 1999; Schnellmann et al., 2002; Guyard et al., 2007) or be in association with a volcanic event (Chapron et al., 2006; Villarosa et al., 2006). Earthquakeinduced sediment liquefaction is referring to temporary suspension of sediment grains in the pore fluid due to cyclic loading (Moretti et al., 1999) and result in complete loss of sediment strength.

Rapid lake level changes may also affect sediment pore pressure and favour sub aquatic slides (Fanetti et al., 2008; Strasser and Anselmetti, 2008). Slope overloading can, in addition, initiate mass wasting processes in lacustrine environments characterized by high (or fluctuating) sedimentation rates and significant amount of free gas reducing sediment shear strength (Chapron et al., 2004; Cauchon-Voyer et al., 2008). Biogenic gases production from the mineralisation of organic matter in the sediments of Lake Pavin are clearly detected above and below the monimolimnion by frequent gas expansion cracks in organic rich sediments 
retrieved at site PAV08, and by the very limited penetration of the acoustic signal in the deep basin (Figs. 3 and 5). Available chronologies on the plateau (this study) and in the deep basin (Schetler et al., 2007) highlight high and variable sedimentation rates. Lake Pavin sediments are therefore likely less stable, especially along the steep slopes.

The regional seismicity of the study area is presently moderate (Lambert et al., 1997; Boivin et al., 2004; www. sisfrance.net): five events (with MSK intensities between 4 and 7) were located at less than $20 \mathrm{~km}$ from Lake Pavin since AD 1833; and two stronger regional events were located at ca. $100 \mathrm{~km}$ from Lake Pavin in AD 1477 (MSK 7.5) and AD 1490 (MSK 8). None of these historical earthquakes seems, however, to have affected the sedimentation of Lake Pavin. No evidence for Late Holocene tephra layers where found in Lake Pavin sedimentary sequence, thus comforting the postulate that the Pavin eruption was the latest in the study area. This suggests that the most probable triggering factor for the two generations of mass wasting events documented in this study is a combination of both abrupt lake level changes and reduced stability of gas-rich lacustrine sediments draping steep slopes.

Little is known about hydrological changes over the last two millennia in the Massif Central region, but a pioneer stratigraphic study by Coûteaux (1984) suggested significant lake level changes during the mid Holocene in the Issarlès maar lake located at ca. $90 \mathrm{~km} \mathrm{SE}$ from Lake Pavin. The only available regional paleo-hydrological reconstructions at $45^{\circ} \mathrm{N}$ were performed at Lake Paladru (Brochier et al., 2007) in the French alpine foreland (ca. $200 \mathrm{~km}$ East from Lake Pavin) and Magny (2004) established a synthesis of Holocene lake level changes in western Europe (from 26 lakes in the Jura mountains, the northern French Pre-Alps and the Swiss Plateau). Magny (2004) documented in particular phases of higher lake levels between AD 650 and 850 (1300-1100 cal BP); AD 1200 and $1300(750-650 \mathrm{cal} \mathrm{BP})$ and since AD 1394. Brochier et al. (2007) documented a first phase of low lake level between AD 500 and 750, but also drastic and abrupt drops in lake level from AD 890 to 946 and from AD 974 to 1040. A short period of lake level rise is detected in Lake Paladru from AD 946 to 974 and a high lake level phase initiated after AD 1040. While the timing of the last lake level rise in Lake Paladru may be linked to local and anthropogenic factors, others lake level fluctuations were interpreted as related to large scale changes in climate conditions (e.g. the Medieval Warm Period and the onset of the Little Ice Age). Consequently, in Lake Pavin, it seems likely that subaquatic destabilisations between AD 580-640 and between AD 1200-1300 occurred during periods of climatic and lake level fluctuations. The last mass wasting event in Lake Pavin thus occurred during a period of regional higher lake level, while the first event apparently occurred during a period of lower lake level in the French alpine foreland, but just before the onset of a lake transgression in mid European lakes.
It seems therefore possible that mass wasting events in Lake Pavin occurred preferentially during period of lake level rise. In any case, changes in sediment pore pressure resulting from lake level change, may have favoured sub-aquatic mass wasting events in gas-rich deposits accumulated on the plateau of Lake Pavin.

In the context of our study area, lake level fluctuations in Pavin crater can either result from geomorphologic changes at the outlet (i.e. outlet continuous incision or outlet outburst) or from climate conditions (i.e. changes in the precipitation/evaporation ratio). While phases of high lake level are controlled by the altitude of the outlet, phases of low lake level maybe favoured in Lake Pavin by the possible occurrence of a sub-aquatic outflow detected on the multibeam bathymetric data. Water seepage may indeed produce the pluri-metric depression occurring by $20 \mathrm{~m}$ water depth, observed at only $100 \mathrm{~m} \mathrm{SE}$ from the sub-aerial outlet (Fig. 9). The existence of such an outflow should, however, be confirmed by divers and eventually taken into consideration for hydrological investigations in this crater lake.

Significant lake level drops during the history of Lake Pavin are, in addition, suggested by the morphology of the outlet incision within the crater rim (Fig. 1): the present-day $600 \mathrm{~m}$ wide and $53 \mathrm{~m}$ deep incision has probably been favoured by the spatial variation in the cohesion and permeability of crater materials. The outlet incision was already significant in the late XVIIIth century according to the oldest available paintings from Lake Pavin made by H. Lecoq in AD 1867 (Fig. 9) and may result either from continuous processes reaching weaknesses in the composition of the outlet sill, or from the occurrence of one (or successive) outburst(s) of the northern crater wall where the present outlet occurs. Such an outburst event can form a negative depression wave spreading upstream into the lake (Simpson and Castelltort, 2006) and will result in rapid lake level fall (in the order of several meters). Such type of abrupt lake level changes could also be responsible for the development of a sub-aquatic slide similar to the ones documented in the basin fill of Lake Pavin. Alternatively, waves induced by sub-aquatic slides could as well impact the outlet, enhance its erosion and eventually trigger a lake outburst.

\subsection{Implications for natural hazards associated with recent (meromictic) maar lakes}

The case study from Lake Pavin suggests that even when subaerial slope instabilities are limited along the inner slopes of a recent crater, significant natural hazards can be related to sub-aquatic slope stabilities. Although several triggering mechanisms can be responsible for the development of the two generations of prehistoric mass wasting phenomena identified in Lake Pavin, these events may have had important implications in this meromictic maar lake: 
(i) Reworking and remoulding gas-rich sediments along the slopes and in the deep basin may for instance release a significant amount of gas in the water column and increase gas content in the monimolimnion, in particular if the slide scar occurs at a water depth close to (or below) the upper limit of the monimolimnion. The sudden deposition of a large sediment load in the deep basin of a meromictic maar lake resulting from a sub-aquatic mass wasting event occurring elsewhere in the lake basin can, in addition, trigger a sudden gas release from profundal sediments to the monimolimnion. Together with the displacement of water during a mass wasting event, such possible changes in gas content might affect a) the onset of lacustrine meromicticity, b) the stability of the water column (especially in the monimolimnion) and c) eventually favour the development of a limnic eruption (Evans et al., 1994; Mott and Woods, 2010).

(ii) Sub-aqueous landslides can trigger violent waves according to their size and velocity (Harbitz, 1992). In a small maar lake such waves can easily be reflected along the lake shore and eventually favour the rupture of the lake outlet (i.e. lake outburst). Waves can also be amplified and entering into resonance (i.e. formation of a seiche effect). Depending on the slide scar location and on the lake bathymetry, such a seiche effect can produce cyclic loading at the outlet and result in the development of a lake outburst. A seiche effect associated with subaqueous landslides can also develop a specific type of turbidite (i.e. seiche deposit, cf. Chapron et al., 1999) in the deep flat basin.

(iii) Spontaneous or induced lake outburst will result in a formation of a lahar flood or a debris flow downstream the crater, and in an abrupt lake level drop, which can affect lacustrine sediment stability, but also gas stability in the water column and eventually favour a limnic eruption.

To fully understand natural hazards associated with meromictic maar lakes, and to test the impact of these different scenarios in Lake Pavin, future studies should therefore determine gas compositions and content in the sediments from littoral and deep environments in Lake Pavin. This is necessary to test the potential impact of mass wasting processes on the development of lacustrine meromicticity and eventually to include them into hydro- and geo-chemical models. To better understand the impact of sub-aquatic landslides on the water column (propagation of waves and development of seiche effect) and on the lake outlet, numerical modelling should also be performed and considering the lake bathymetry, the volume and the source area of the two slide events documented in this study. The potential links between sub-aquatic landslides, outlet incision and ignition of debris flows downstream the crater could also be established by precise dating and detailed sedimentological characterizations of prehistorical turbidite deposits in the deep basin of Lake Pavin mentioned by Schwab et al. (2009) and of recent debris flow deposits suggested by Lavina and del Rosso (2008) in the Couze Pavin valley.

In other recent meromictic maar lakes such as lakes Monoun and Nyos in Cameroon, known to have been affected by gas burst events in 1984 and 1986, respectively, the possible triggering factors and the evolution of processes during a limnic eruption are still controversial (Sigurdsson et al., 1987; Pourchet et al., 1988, 1990; Tazieff, 1989; Evans et al., 1993; Freeth and Rex, 2000; Mott and Woods, 2010). In Lake Monoun for example, the water density stratification seems to have been disturbed by earthquake shaking and sub-aquatic landslides which triggered overturn of the lake, caused a gas burst at the surface and locally generated waves up to $5 \mathrm{~m}$ high (Sigurdsson et al., 1987). In Lake Nyos large waves were also documented during the gas burst, and a high resolution seismic profile acquired in 1991 highlights the occurrence of a up to $4 \mathrm{~m}$ thick turbidite deposit in the deep flat bottom of the lake, formed by the 1986 event on top of gas-rich sediments (Leenhardt, 1991). The thickness of this typical transparent acoustic facies shown in Fig. 10, suggests the occurrence of significant mass wasting processes (cf. Chapron et al., 2006) and sediment mixing in Lake Nyos during the 1986 event. This turbidite deposit also provides an explanation for sediment mixing and homogenization deduced from a $1 \mathrm{~m}$ long sediment core lithology and ${ }^{210} \mathrm{~Pb}$ measurements (Pourchet et al., 1990; Piboule et al., 1990). Thus, in these dangerous tropical maar lakes, multibeam bathymetric and sub bottom profiling surveys are still necessary to document sedimentary environments and to optimise the location of long sediment cores. Like in others recent maar lakes from around the world, the identification of mass wasting deposits, turbidite deposits or seiche deposits on cores and seismic profiles, together with numerical modelling would be helpful to better understand driving forces and recurrence time of catastrophic limnic eruptions.

Finally, since the development of a sub-aquatic plateau is a frequent characteristic in maar lakes world wide (Couteaux, 1984; Giresse et al., 1991; Chondrogianni et al., 1996; Ramrath et al., 1999; Anzidei et al., 2008; Mazzanti and Bozzano, 2009; Bani et al., 2009) these specific geomorphological features may represent key sub-aquatic environments allowing (i) the freezing of mass wasting events originating from up slopes, and/or (ii) a potential sediment source area for mass wasting events occurring along their edges and essentially remoulding steep crater slopes and deep flat basin sediments. In this perspective the case study from Lake Pavin may provide a better understanding of driving factors leading to the formation of mass movements in maar lakes. 


\section{Conclusions}

Combining high-resolution seismic reflection profiling and multibeam bathymetry in Lake Pavin allowed optimising the location of PAV08 coring site on a small sub-aquatic plateau. Radiocarbon dating of organic-rich lacustrine sediments at the base of this core just above Pavin crater material confirms the mid Holocene age of the Pavin phreatomagmatic event: $6090{ }^{14} \mathrm{C}$ BP $(6970 \pm 60 \mathrm{yrs}$ cal BP). No more recent explosive volcanic event was documented within the basin fill of this maar lake. This new data set in Lake Pavin highlights a wide range of gravity reworking phenomena affecting both the inner crater walls and lacustrine material. This study suggests in particular that maar lakes dominated by biogenic sedimentation, are characterized by gas-rich sediments which are poorly stable along the steep sub-aquatic slopes of the crater. Sub-aquatic mass wasting phenomena may thus be easily triggered either by lake level changes, earthquake shaking or large waves resulting from coastal landslide(s) or from maar lake outlet outburst(s). Gas released from the sediments to the water column during a mass wasting event, may have in addition a significant influence on the development of lacustrine meromixis and on the gas stability in deep waters. Such phenomena may further explain the occurrence of dangerous gas burst in contrasted worldwide meromictic maar lake systems.

In Lake Pavin, a first slump deposit dated between AD 580-640 at site PAV08, and the formation before AD 1300 (possibly around AD 1200) of a large slide scar mapped at $50 \mathrm{~m}$ water depth, both occurred during periods of contrasted climatic conditions associated with regional lake level fluctuations (and in particular lake level rise). These two prehistoric mass wasting events were thus probably triggered by rapid lake level changes due to climate variability, although earthquake shaking or lake outlet outburst can not be ruled out. In order to precise the origin and the consequences of these two large mass wasting events in Lake Pavin, future studies should combine numerical simulations testing the possible generation of waves by sub-aquatic slides and their impact at the outlet, together with radiocarbon dating of mass wasting deposits in the deep basin of Lake Pavin as well as in nearby lakes- and a detailed chrono-stratigraphic study of debris flow deposits in the Couze Pavin valley.

Acknowledgements. This study was funded by the MEEDDAT project of the Direction Départementale de l'Equipement et de 1'Agriculture (DDEA Puy-de-Dôme). We wish to thanks Philippe Rocher (BRGM-Auvergne, Clermont-Ferrand) for providing us the multibeam bathymetric data, Fabien Arnaud (EDYTEM, Savoie University, Chambéry) for coring operations, Boris Vannière (LCE, Franche Comté University, Besançon) for Geotek facilities, and Koen de Ryker and Tina Missiaen from the RCMG (Ghent University) for seismic data acquisition. Charles Gumiaux (ISTO) provided the digital elevation model of Montchal-Pavin area presented in Fig. 1. The seismic data were interpreted at Orléans
University using the Kingdom Suite ${ }^{\mathrm{TM}}$ software developed by Seismic Micro-Technology Inc. This manuscript benefited from fruitful scientific discussions with Jean-Pierre Henriet (RCMG, Ghent), Markus Schwab (GZF, Potsdam), Pierre Lavina (Terre $\&$ Volcans) and Pierre Boivin (Observatoire de Physique du Globe de Clermont-Ferrand, CNRS-Université Blaise-Pascal, Clermont-Ferrand). We finely thank the two anonymous reviewers and the editor for their constructive comments.

Edited by: J. Marti

Reviewed by: two anonymous referees

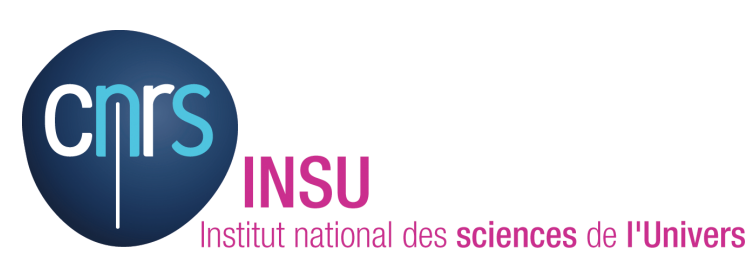

The publication of this article is financed by CNRS-INSU.

\section{References}

Aeschbach-Hertig, W., Hofer, M., Kipfer, R., Imboden, D. M., and Wieler, R.: Accumulation of mantle gases in a permanently stratified volcanic lake (Lac Pavin, France), Geochim. Cosmochim. Ac., 63, 3357-3372, 1999.

Albéric, P., Viollier, E., Jézéquel, D., Grosbois, C., and Michard, G.: Interactions between trace elements and dissolved organic matter in the stagnant anoxic deep layer of a meromictic lake, Limnol. Oceanogr., 45, 1088-1096, 2000.

Anselmetti, F., Ariztegui, D., de Batist, M., Gebhardts, A., Haberzettl, T., Niessens, F., Ohlendorf, C., and Zolitschka, B.: Environmental history of southern Patagonia unravelled by the seismic stratigraphy of Laguna Potrok Aike, Sedimentology, 56(4), 873-892, doi:10.1111/j.1365-3091.2008.01002.x, 2009.

Anzidei, M., Carapezza, M.L., Esposito, A., Giordano, G., Lelli, M., and Tarchini, L.: The Albano maar lake high resolution bathymetry and disolved $\mathrm{CO}_{2}$ budget (Colli Albani volcano, Italy): constrains to hazard evaluation, J. Volcanol. Geoth. Res., 171, 258-268, 2008.

Assayag, N., Jézéquel, D., Ader, M., Viollier, E., Michard, G., Prévot, F., and Agrinier, P.: Hydrological budget, carbon sources and biogeochemical processes in Lac Pavin (France): Constrains from $\delta^{18} \mathrm{O}$ of water and $\delta^{13} \mathrm{C}$ of dissolved inorganic carbon, Appl. Geochem., 23, 2800-2816, 2008.

Bacon, C., Gardner, J., Mayer, L., Buktenica, M., Dartnell, P., Ramsey, D., and Robinson, J.: Morphology, volcanism, and mass wasting in Crater Lake, Oregon, Geol. Soc. Am. Bull., 114, 675692, 2002.

Bani, P., Join, J.-L., Cronin, S. J., Lardy, M., Rouet, I., and Garaebiti, E.: Characteristics of the summit lakes of Ambae volcano and their potential for generating lahars, Nat. Hazards Earth Syst. Sci., 9, 1471-1478, doi:10.5194/nhess-9-1471-2009, 2009.

Boivin, P., Besson, J.-C., Briot, D., Camus, G., de Goër de Herve, A., Gougaud, A., Labazuy, P., de Larouzière, F.-D., Livet, M., Mergoil, J., Mialler, D., Morel, J.-M., Vernet, G., and Vincent, P.M.: Volcanologie de la Chaîne des Puys, 4eme Edition, Edition 
du Parc Régional des Volcans d'Auvergne, Aydat, 179 pp., 2004 (in French).

Bourdier, J. L.: Contribution à l'étude volcanologique de deux secteurs d'intérêt géothermique dans le Mont Dore: le groupe holocène du Pavin et le Massif du Sancy, unpublished Ph.D. thesis, Université de Clermont-Ferrand II, 180 pp., 1980.

Brauer, A., Haug, G., Dulski, P., Sigman, D., and Negendank, J.: An abrupt wind shift in western Europe at the onset of the younger Dryas cold period, Nat. Geosci., 1, 520-523, 2008.

Brochier, J.-L., Borel, J.-L., and Druart, J.-C.: Les variation paléoenvironnementales de 1000 avant à 1000 après J.C. et la question des "optima" climatiques de l'Antiquité tardive et du Moyen Age sur le piedmont des Alpes du Nord à Colletière, Lac de Paladru, France, Quaternaire, 18, 253-270, 2007 (in French).

Camus, G., Michard, G., Olive, P., Boivin, P., Desgranges, P., Jézéquel, D., Meybeck, M., Peyrus, J. C., Vinson, J. M., Viollier, E., and Kornprobst, J.: Risques d'éruptions gazuese carbonique en Auvergne, B. Soc. Geol. Fr., 164, 767-781, 1993 (in French).

Caracausi, A., Nuccio, P. M., Favara, R., Nicolosi, M., and Paternóster, M.: Gas hazard assessment at the Monticchio crater lakes of Mt Vulture, a volcano in Southern Italy, Terra Nova, 21, 83-87, 2009.

Cauchon-Voyer, G., Locat, J., and St-Onge, G.: Late-Quaternary morpho-sedimentology and subamrine mass movements of the Betsiamites area, Lower St. Lawrence Estuary, Quebec, Canada, Mar. Geol., 251, 233-252, 2008.

Coûteaux, M. : Recherches pollenanalytiques au Lac d'Issarlès (Ardèche, France): Evolution de la végétation et fluctuations lacustres, B. Soc. Roy. Bot. Belg., 117, 197-217, 1984 (in French).

Chapron, E., Beck, C., Pourchet, M., and Deconinck, J. F.: $1822 \mathrm{AD}$ earthquake-triggered homogenite in Lake Le Bourget (NW Alps), Terra Nova, 11(2/3), 86-92, 1999.

Chapron, E., Van Rensbergen, P., De Batist, M., Beck, C., and Henriet, J. P.: Fluid escape features as a precursor of a large sublacustrine sediment slide in Lake Le Bourget, NW Alps, France, Terra Nova, 16, 305-311, 2004.

Chapron, E., Ariztegui, D., Mulsow, S., Villarosa, G., Pino, M., Outes, V., Juviginié, E., and Crivelli, E.: Impact of 1960 major subduction earthquake in Northern Patagonia (Chile, Argentina), Quatern. Int., 158, 58-71, 2006.

Chondrogianni, C., Ariztegui, D., Niessen, F., Ohlendorf, C., and Lister, G.: Late Pleistocene and Holocene sedimentation in Lake Albano and Lake Nemi (central Italy), in: Palaeoenvironmental Analysis of Italian Crater Lake and Adriatic Sediments, edited by: Guilizzoni, P. and Oldfield, F., Memoire dell'istituto italiano di Idrobiologia, 55, 23-38, 1996.

Delibrias, G., Guillier, M. T., and Labeyrie, J.: Gif natural radiocarbon measurements VII, Radiocarbon, 14, 280-320, 1972.

Evans, W. C., White, L. D., Tuttle, M. L., Kling, G. W., Tanyileke, G., and Michel, R.: Six years of change at Lake Nyos, Cameroon, yield clues to the past and cautions for the future, Geochem. J., 28, 139-162, 1994.

Fanetti, D., Anselmetti, F., Chapron, E., Sturm, M., and Vezzoli, L.: Megaturbidite deposits in the Holocene basin fill of Lake Como (Southern Alps, Italy), Palaeogeogr. PPalaeocl., 259, 323-340, 2008.

Freeth, S. J. and Rex, D. C.: Constraints on the age of Lake Nyos, Cameroon, J. Volcanol. Geoth. Res., 97, 261-269, 2000.
Giresse, P., Maley, J., and Kelts, K.: Sedimentation and paleoenvironment in crater lake Barombi Mbo, Cameroon, during the last 25000 years, Sedimentary Geol., 71, 151-175, 1991.

Guenet, P. and Reille, M.: Datation par l'analyse pollinique des eruptions des plus jeunes volcans d'Auvergne (Besse-enChandesse, Puy de Dome, France), Cahiers du Quaternaire, 16, 175-180, 1991 (in French).

Guyard, H., St Onge, G., Chapron, E., Anselmetti, F., and Francus, P.: The AD 1881 earthquake-triggered slump and late Holocene flood-induced turbidites from Proglacial lake Bramant, Western French Alps, in: Submarine Mass Movements and Their Consequences, edited by: Lykousis, V., Sakellariou, D., and Locat, J., Springer, 279-286, 2007.

Harbitz, C. B.: Model simulations of tsunamis generated by the Storegga Slides, Mar. Geol., 105(1-4), 1-21, 1992.

Joyce, K., Samsonov, S., Manville, V., Jongens, R., Grettinger, A., and Cronin, S.: Remote sensing data types and techniques for lahar path detection: a case study at Mt Ruapehu, New Zealand, Remonte Sens. Environ., 13, 1778-1786, 2009.

Juvigné, E.: Distribution of widespread late glacial and holocene tephra beds in the French Central Massif, Quatern. Int., 14, 181$185,1992$.

Juvigné, E. and Gilot, E.: Ages et zones de dispersion de téphra émises par les volcans du Montcineyre et du Lac Pavin (Massif Central, France), Zeitschrift deutschen geologischen Gesellschaft, 137, 613-623, 1986 (in French).

Lambert, J., Levret-Albaret, A., Czitrom, G., Dubie, J. Y., and Godefroy, P.: Les tremblements de terre en France, Editions BRGM, Orléans, 127 pp., 1997.

Lavina, P. and del Rosso, T.: Le complexe volcanique Montchal Pavin - Montcineyre: nouvelles stratigraphie, téphrochronologie et datations, vers une réévaluation de l'aléa volcano-tectonique en Auvergne, 22ème Réunion des Sciences de la Terre, Nancy, France, Abstract, Volume, 2008 (in French).

Ledoux, G., Lajeunesse, P., Chapron, E., and St Onge, G.: Multibeam bathymetry investigations of mass movements in Lake Le Bourget (NW Alps, France) using a portable platform, in: Submarine Mass Movements and Their Consequences, edited by: Mosher, D. C., Shipp, R. C., Moscardelli, L., et al., Springer Science + Business Media B.V., Adv. Nat. Technol. Haz., 28, 423-434, 2010.

Leenhardt, O.: La catastrophe du lac Nyos, Aspects scientifiques, Géologues, 96, 13-24, 1991 (in French).

Locat, J. and Lee, H.: Submarine landslides: advances and challenges, Can. Geotech. J., 39, 193-212, 2002.

Martin, J.-M., Meybeck, M., Nijampurkar, V. N., and Somayajulu, B. L. K.: ${ }^{210} \mathrm{~Pb},{ }^{226} \mathrm{Ra}$ and ${ }^{32} \mathrm{Si}$ in Pavin lake (Massif Central, France), Chem. Geol. (Isotope Geoscience Section), 94, 173181, 1992.

Masson, D. G., Harbitz, C. B., Wynn, R. B., Pedersen, G., and Lovholt, F.: Submarine landslides: processes, triggers and hazard prediction, Philos. T. Roy. Soc. A, 364, 200-2039, 2006.

Mazzanti, P. and Bozzano, F.: An equivalent fluid/equivalent medium approach for the numerical simulation of coastal landslides propagation: theory and case studies, Nat. Hazards Earth Syst. Sci., 9, 1941-1952, doi:10.5194/nhess-9-1941-2009, 2009.

Morreti, M., Alfaro, P., Caselles, O., and Canas, J. A.: Modelling seismites with a digital shaking table, Tectonophysics, 304, 369383, 1999. 
Mott, R. W. and Woods, A. W.: A model of overturn of $\mathrm{CO}_{2}$ laden lakes triggered by bottom mixing, J. Volcanol. Geoth. Res., 192(3-4), 151-158, doi:10.1016/j.jvolgeores.2010.02.009, 2010.

Mulder, T. and Cochonat, P.: Classification of offshore mass movements, J. Sediment. Geol., 66, 43-57, 1996.

Nisbet, E. and Piper, D.: Giant submarine landslides, Nature, 392, 329-330, 1998.

Oldfield, F.: The PALICLAS project: synthesis and overview, Memoire dell'istituto italiano di Idrobiologia, 55, 329-357, 1996.

Piboule, M., Pourchet, M., Bouchez, R., Amosse, J., Brenac, P., Maley, J., Pinglot, J. F., and Vincent, C.: Radiometric studies of Lake Nyos (Cameroon) sediments: evidence of strong mixing and excess ${ }^{210} \mathrm{~Pb}$, J. Volcanol. Geoth. Res., 42, 363-372, 1990.

Pourchet, M., Pinglot, J. F., Maley, J., and Mélières, M. A.: Another gas burst in a Cameroon lake?, Nature, 334, p. 655, 1988.

Pourchet, M., Pinglot, J. F., Maley, J., Mélières, M. A., and Zogning, A.: Lake Bambuluwé (Cameroon): building-up the same scenarios as Lake Nyos?, J. Volcanol. Geoth. Res., 42, 397-400, 1990.

Ramrath, A., Zolitschka, B., Wulf, S., and Negendank, J. F. W.: Late Pleistocene climatic variations as recorded in two Italian maar lakes (Lago di Mezzano, Lago Grande di Monticchio), Quaternary Sci. Rev., 18, 977-992, 1999.

Rice, A.: Rollover in volcanic crater lakes: a possible cause for Lake Nyos type disasters, J. Volcanol. Geoth. Res., 97, 233-239, 2000.

Schettler, G., Schwab, M. J., and Stebich, M.: A 700-year record of climate change based on geochemical and palynological data from varved sediments (Lac Pavin, France), Chem. Geol. 240, 11-35, 2007.

Schettler, G. and Albéric, P.: Laghi di Monticchio (Southern Italy, Region Basilicata): genesis of sediments - a geochemical study, J. Paleolimnol., 40, 529-556, 2008.

Schnellman, M., Anselmetti, F. S., Giardini, D., McKenzie, J. A., and Ward, S. N.: Prehistoric earthquake history revealed by lacustrine slump deposits, Geology, 30, 1131-1134, 2002.

Schwab, M. J., Schettler, G., Bruchmann, C., Acksel, D., Negendank, J. F. W., and Brauer, A.: Stratigraphy, chronology and paleoenvironment information of the sediment record from Lac Pavin, Massif Central (France), International Meeting-Lake Pavin and Other Meromictic Lakes, Besse et St Anastaise, France, Abstract p. 30, 14-16 May 2009.
Siegenthaler, C., Finger, W., Kelts, K., and Wang, S.: Earthquake and seiche deposits in Lake Lucerne, Switzerland, Eclogae Geologica Helvetiae, 80, 241-260, 1987.

Sifeddine, A., Bertrand, P., Lallier-Vergès, E., and Patience, A. J.: The relationship between lacustrine organic sedimentation and palaeoclimatic variations: lac du Bouchet (Massif Central, France), Quaternary Sci. Rev., 15, 203-212, 1996.

Sigurdsson, H., Devine, J. D., Tchua, F. M., Presser, F. M., Pringle, M. K. W., and Evans, W. C.: Origin of the lethal gas burst from Lake Monoun, Cameroun, J. Volcanol. Geoth. Res., 31, 1-16, 1987.

Simpson, G. and Castelltort, S.: Coupled model of surface water flow, sediment transport and morphological evolution, Comput. Geosci., 32, 1600-1614, 2006.

Stebich, M., Bruchmann, C., Khulbe, T., and Negendank, J.: Vegetation history, human impact and climate change during the last 700 years recorded in annually laminated sediments of Lac Pavin, France, Rev. Palaeobot. Palyno., 133, 115-133, 2005.

Strasser, M. and Anselmetti, F.: Mass-movement events stratigraphy in Lake Zurich: a record of varying seismic and environmental impacts, Beiträge zur Geologie der Schweiz, Geotechnische Serie, 95, 23-41, 2005.

Tazieff, H.: Mechanisms of the Nyos carbon dioxide disaster and of so-called phreatic steam eruptions, J. Volcanol. Geoth. Res., 39, 109-116, 1989.

Thouveny, N., de Beaulieu, J. L., Bonifay, E., Creer, K. M., Guiot, J., Icole, M., Johnsen, S., Jouzel, J., Reille, M., Williams, T., and Williamson, D.: Climate variations in Europe over the past $140-\mathrm{Kyr}$ deduced from rock magnetism, Nature, 371, 503-506, 1994.

Van Rensbergen, P., De Batist, M., Klercx, J., Hus, R., Poort, J., Vanneste, M., Granin, N., Khlystow, O., and Krinitsky, P.: Sublacustrine mud volcanoes and cold seeps caused by dissociation of gas hydrate on Lake Baikal, Geology, 30, 631-634, 2002.

Villarosa, G., Outes, V., Hajduk, A., Fernandez, M., and CrivelliMontero, E.: Explosive volcanism during the Holocene in the Upper Limay River Basin. The effects of ash falls on human societies, Northern Patagonia, Argentina, Quatern.y Int., 158, 44-57, 2006.

Weninger, B. and Jöris, O.: Glacial radiocarbon calibration, the CalPal Program, in: Radiocarbon and Archeology, edited by: Higham, T., Ramsey, C. B., and Owen, C., Fourth International Symposium, Oxford, 2004. 